\title{
A felsőokTATÁs BEFOgadóvá VÁLÁSÁNAK SZEMLÉLETI KERETE ÉS GYAKORLATI MEGVALÓSÍTÁSA a Pécsi Tudományegyetemen
}

\author{
VARGA ARANKA* - DELI KITTI - FODOR BÁLINT
}

Pécsi Tudományegyetem, Bölcsészettudományi Kar, Neveléstudományi Intézet

\begin{abstract}
Kutatásunk a Pécsi Tudományegyetem „Befogadó Egyetem” elnevezésű szakmai-tudományos projektjének elméleti hátterére építve vizsgálta a különböző karokon futó és az inklúzió fókuszában levő hallgatókért zajló tevékenységeket. Vizsgálatunk során a PTE összes karára $(N=10)$ kiterjedő kérdőíves adatfelvétellel és mélyinterjúkkal tártuk fel a befogadást támogató programokat, kerestük a hiányterületeket. Megállapítottuk, hogy a három hallgatói csoport - külföldi, fogyatékos hallgatók és társadalmi hátránynyal küzdő, köztük cigány/roma - méltányos támogatása van jelen leginkább a vizsgált egyetemen. A szervezeti oldalt vizsgálva kutatásunk kimutatta, hogy a befogadást igénylő hallgatók egyéni és közösségi támogatása sokkal inkább jellemzi a vizsgált egyetemet, és kevésbé találhatók olyan beavatkozások, melyek a felsőoktatási környezet egészére vannak hatással. Vizsgálatunkat összegezve megállapítható, hogy a befogadóvá válás folyamatának ismérvei érzékelhetők a PTE-n, de amennyiben a vizsgált folyamatok jövőjét, kívánatos fejlődését nézzük, több ponton szükséges továbblépés.
\end{abstract}

Kulcsszavakः inklúzió, akadémiai kiválóság, Befogadó Egyetem

Building on the theoretical background of the "Inclusive University" programme at the University of Pécs, our research examined the different programmes of each faculty that focus on the target groups of inclusion. Our questionnaire and deep-interview research were extended to all faculties of the University $(N=10)$, examining inclusive programmes and fields that need to be improved. We found out that three student groups were supported mostly (namely: foreign, disabled and disadvantaged/Roma/Gypsy students). Examining the organizational side, we have discovered that the individual and community support of the students in the need of inclusion is more characteristic at the University of Pécs, and there is a smaller number of programmes that involve or affect their whole educational environment. As a summary we can say that the signs of becoming

* Levelező szerző: Varga Aranka, Pécsi Tudományegyetem, Bölcsészettudományi Kar, Neveléstudományi Intézet, Romológia és Nevelésszociológia Tanszék, 7624, Pécs, Ifúság útja 6. E-mail: varga.aranka@pte.hu 
inclusive can already be detected at the University of Pécs - however, the future and desirable development of this process requires further steps in many respects.

Keywords: inclusion, inclusive excellence, Inclusive University

\section{Tudományos előzmények - elméleti keretek}

1 z inklúzió fogalmának tudományos és szakpolitikai megközelítése az utóbbi másfél évtizedben szerte a világon folyamatosan és több szempontból módosult, ugyanis kezdetben a fogyatékos gyermekek sikeres intézményi nevelését jelentette az UNESCO szakmapolitikai mozgalmának köszönhetően (UNESCO 1994, 2005). Az egyik változás, hogy jelentősen bővült a befogadási törekvések fókuszában lévő személyek, csoportok köre, és a befogadást sikeresen támogató tevékenységek egyre inkább kiterjednek minden olyan egyénre, csoportra, akik valamilyen okból gyakorta kizáródnak (exclusion) az oktatásból vagy a társadalom más szegmenséből (UNESCO 2009a, 2009b), illetve a többségi társadalomból érkező társaikhoz képest alulteljesítenek (Connor et al. 2004). További változás, hogy az inklúziót - az oktatási környezetböl továbblépve - társadalmi szinten is egyre inkább fontosabb szemléletként értelmezik (social inclusion). A kölcsönös befogadás a sikeres együttélést nemcsak keretként értelmezi, hanem elengedhetetlennek tartja a környezetbe való sokrétű tartalmi beavatkozást is (Rétby 2013). Felismeri, hogy az inkluzív rendszerekben a méltányosság együtt jár a kiválóság növekedésével.

Napjainkban az inklúzió szemléletének és gyakorlatának kialakítása egyre inkább aktuális kérdéssé válik a felsőoktatásban is, melyben kulcsszerepet játszik a környezet sokszínűvé válása és ezzel összefüggésben a sikeres befogadás igénye. Az Amerikai Egyesült Államokban a Diverse Learning Environment Model (DLE) (Hurtado et al. 2012) kapcsolja össze a méltányos oktatási eredményeket befolyásoló, intézményen belüli (mikro) és az intézményre kívülről ható (makro) erőket. Kutatók különböző csoportjai tudományosan bizonyították, hogy a méltányosság növelése magával hordozza az oktatás minőségi változását, a multikulturális együttéléshez szükséges kompetenciák fejlődését, a lemorzsolódás mérséklését és az akadémiai kiválóság elérését (Hurtado-Ruiz 2015). Ezen alapul az Inclusive Excellence (Milem-Chang-Antonio 2005; Williams-Joseph-Shederick 2005; Baumann et al. 2005) névvel fémjelzett felsőoktatásfejlesztési mozgalom.

A sokszínű egyetemi környezet sajátos intellektuális atmoszférát teremt. Hurtado és munkatársai a felsőoktatási intézményi klíma vizsgálata kapcsán sorra idézik azokat a kutatásokat, amelyek szerint az alulreprezentált csoportok bizonyos kritikus tömegére van szükség ahhoz, hogy szervezeti változás menjen végbe (Arató-Varga 2015, 2018). Amellett érvelnek, hogy a kulturális csoportok intézményi arányával párhuzamosan megváltozik a csoportok közötti társas kapcsolattartás minősége is (Chang-Astin-Kim 2004). A felsőoktatás értékközvetítő funkciója, a kulturális elfogadás attitűdjeinek erősítése, a társadalmi ítéletalkotás képessége akkor fejlődhet, ha a tanulási folyamat aktív információfeldolgozást igényel a hallgatók részéről, s lehetőség van a meglévő és új tudások összeütköztetésére (Chang 2001). 
A felsőoktatás inkluzívvá válása Európában is a figyelem középpontjába került az elmúlt évtizedben azokat a hallgatói csoportokat célozva, akik részvétele jellemzően alulreprezentált ezen a területen - legyen szó a nők, az etnikai kisebbségek, az alacsony társadalmi-gazdasági helyzetűek vagy a migránsok csoportjáról (Casey 2016). Napjainkban az European University Association (EUA) stratégiai kérdésként tekint a felsőoktatási inklúzió és diverzitás témakörére. A 2018-ban publikált esettanulmányokból kiderül, hogy az egyes országokban megvalósuló fejlesztések különböző mértékủek és lefolyásúak, mivel eltérőek a helyi sajátosságok, más a társadalom gazdasági-szociális struktúrája és a marginalizálódás veszélyének kitett csoportok köre. Európa különböző felsőoktatási intézményeiben megfigyelhető, hogy intézményi szinten törekednek arra, hogy a felsőoktatás részévé váljon a sokszínűség, a méltányosság és az inklúzió, ezért különböző stratégiai lépésekkel igyekeznek ezek az intézmények egyenlő részvételt és lehetőségeket biztosítani az alulreprezentált csoportoknak (Claeys-Kulik-Jorgensen 2018).

Megismerve számos európai egyetem intézkedéseit elmondható, hogy egyazon célért tevékenykednek egy-egy célcsoportra kiemelten fókuszálva, és olyan stratégiai lépéseket követnek, amelyek specifikusan illeszkednek az adott országok jellemzőihez, sajátosságaihoz. Hangsúlyos szerepet kap mindenhol a vezetői elköteleződés, az együttmüködések kialakítása az egyetemen belül és külső szervezetekkel, a mentorálás, az önkénteskedés, a tudományosan megalapozott és alátámasztott gyakorlatorientáltság és az idegen nyelvi fejlesztés (Claeys-Kulik-Jorgensen 2018). Jól látható, hogy Európa-szerte több felsőoktatási intézmény fókuszál a nemi diverzitás kialakítására, a fogyatékos hallgatók és oktatók számára a méltányos lehetőségek biztosítására, a menekültek és menedékjogot igénylők akadémiai kiválóságának elősegítésére. Ebbe a vizsgálati sorba illeszkedik jelen kutatásunk, mely a Pécsi Tudományegyetemen - a magyarországi kontextushoz igazítva - vizsgálja az inkluzivitás helyzetét.

\section{Kutatói kérdések}

Vizsgálatunk annak feltárását célozza, hogy mi jellemzi a Pécsi Tudományegyetemet a befogadás szempontjából. Tudjuk, hogy az elmúlt években egyre nagyobb számban jelennek meg a PTE-n az inklúzió szempontjából fókuszban lévő hallgatói csoportok, és ismerünk őket támogató programokat is.

Kíváncsiak vagyunk a magyarországi felsőoktatásban alulreprezentált csoportok számosságára, arányára, mindezek változására a PTE-n. Az is kérdés, hogy a különböző karok ezen csoportok közül mely hallgatói csoportokra és milyen módon fókuszálnak? Miféle befogadást célzó programok találhatók? Hogyan segítik ezek a programok a célcsoportjukba tartozó hallgatók bekerülését és előrehaladását? Milyen sikerek és nehézségek figyelhetők meg az egyes szolgáltatások müködtetése során?

A z alulreprezentált hallgatói csoportok és méltányos támogatásuk vizsgálata mellett fókuszálunk az intézményi környezetre is. Kérdésünk, hogy vannak-e olyan programok, melyek a környezet inkluzivitásának növelését célozzák? Találhatók-e az oktatók és a személyzet felkészítését, az egyetemi polgárok érzékenyítését szolgáló programok, akciók, léteznek-e a curriculum átalakítását célzó beavatkozások, melyek az inkluzív klíma és az akadémiai kiválóság növelését eredményezhetik?

Úgy véljük, helyzetfeltárásunk alapján láthatóvá válik, hogy a PTE mely csoportok befogadásának növelésére fókuszál, és mely csoportokra kell még nagyobb figyelmet for- 
dítania. Feltételezhetően látni fogjuk azt is, hogy a befogadóvá válás mely „lépcsőfokán” tart a vizsgált intézmény (1. ábra), és javaslatot tudunk tenni a továbblépéshez szükséges teendőkre.

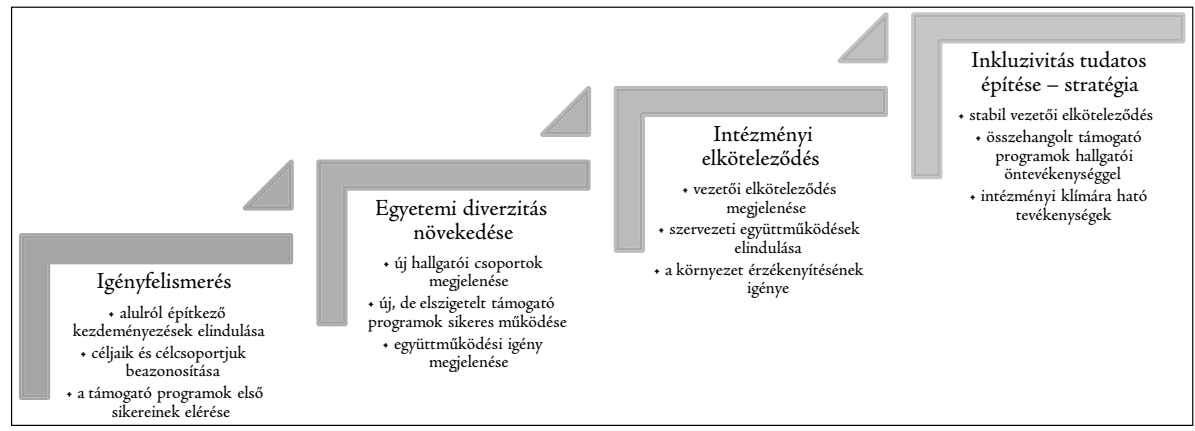

1. ábra: Az inkluzivitás kiterjedésének lépcsőfokai (saját szerkesztés)

\section{Módszertan}

Makrostatisztikai adatokat felhasználva elemeztük a Pécsi Tudományegyetem hallgatói diverzitásának helyzetét. Azt vizsgáltuk, hogy milyen csoportok méltányos támogatással segített befogadására fókuszálnak a PTE-n, és ezen hallgatói csoportok számaránya miként változott az elmúlt években. Támaszkodtunk országos és egyetemi adatbázisokra és megelőző kutatások eredményeire. Igyekszünk a PTE-s adatokat országos és más egyetemek adataival összevetésben is bemutatni.

A kérdőíves kutatásunk kiterjedt a Pécsi Tudományegyetem összes karára $(N=10)$, feltárva a karok által támogatott - a sokszínűség fókuszában álló - csoportokat és a támogatások különböző formáit, típusait. Az egyes karok dékánjai 2018 őszén töltötték ki kérdőívünket, melyben rákérdeztünk, hogy mely hallgatói csoportok támogatására fordít figyelmet az adott kar, ez milyen érintettséggel és kiterjedtséggel jelenik meg. Azt is leírhatták, hogy mely befogadást erősítő fejlesztéseiket tartják fontosnak. A kitöltőket kértük, hogy az említett programok, támogató jó gyakorlatok tartalmát is részletezzék. A kérdőív zárt és nyitott kérdésből állt, melyek feldolgozását egyszerü összegzéssel és tartalomelemzéssel végeztük.

A PTE inkluzivitásának mélyebb megismeréséhez, a méltányos szolgáltatások összevetéséhez, az esetleges hiányok megismeréséhez félig strukturált mélyinterjúkat $(N=10)$ készítettünk azokkal a szolgáltatásvezetőkkel, akiket a kérdőíves adatfelvétel alapján úgy ítéltünk meg, hogy a leginkább aktívak a gyakorlatban. Kérdéseinkkel azt céloztuk, hogy részletesen megismerjük ezen szolgáltatások kialakulásának és létrejöttének okát, jelenlegi müködését, sikereiket, nehézségeiket és jövőbeli céljaikat. A mélyinterjúk felvételére 2019 tavaszán került sor, a szövegek feldolgozásához tartalomelemzést alkalmaztunk.

\section{$\mathrm{A} z$ inklúzió fókuszában lévő hallgatói csoportokról}

A tudományos vizsgálódások Európa-szerte az alábbi szempontok figyelembevételével különböztetik meg a felsőoktatásban alulreprezentált csoportokat: 1) nemek közötti eltérések 2) életkor szerinti különbségek 3) felnőttek felsőoktatási részvétele 4) alacsony 
gazdasági-társadalmi státusz, háttér 5) szülők alacsony iskolai végzettsége 6) etnikai, kulturális, vallási vagy nyelvi kisebbséghez való tartozás 7) bevándorló státusz 8) fogyatékosság (Széll 2016).

Több magyarországi nagyobb egyetem honlapját ${ }^{1}$ megvizsgálva azt találtuk, hogy részletesen lebontott és nyilvánosan elérhető adatok vannak a külföldi és a magyar hallgatók arányáról, a képzési szintek és a finanszírozási formák szerinti eloszlásról. Ezek az adatok azonban nem minden esetben frissek. A Pécsi Tudományegyetemen is megfigyelhető az az országos tendencia, melyet a külföldi hallgatók arányának folyamatos növekedése mutat (1. táblázat). Az információhiány, a szociális, kulturális és nyelvi nehézségek miatt a külföldi hallgatói csoport befogadását is kiemelten kezeljük, különösen amiatt, hogy ez a hallgatói csoport már kritikus tömegnek tekinthető a PTE-n (Arató-Varga 2015, 2018).

1. táblázat: Hallgatói összlétszám és a külföldi hallgatók létszámának eloszlása a PTE-n a 2015-2018 közötti időszakban

\begin{tabular}{lccc}
\hline \multirow{2}{*}{ Tanév } & \multirow{2}{*}{$\begin{array}{c}\text { Hallgatói } \\
\text { összlétszám }\end{array}$} & \multicolumn{2}{c}{ Külföldi hallgatók } \\
\cline { 3 - 4 } & & létszáma (fö) & aránya (\%) \\
\hline 2015 & 19799 & 2776 & 14,02 \\
2016 & 19684 & 3200 & 16,26 \\
2017 & 20075 & 3741 & 18,64 \\
2018 & 20082 & 4032 & 20,08 \\
\hline
\end{tabular}

Az inklúzió fókuszában lévő további csoport a fogyatékos hallgatók, akik személyes sajátosságaik miatt kerültek ebbe a csoportba (Duncan 2014). A 2010-2014-es országos adatokat vizsgálva látható, hogy a fogyatékos emberek, így a hallgatók létszáma is csökkent, ennek több oka is lehet, melyet jelen tanulmányunknak nem célja vizsgálni (Laki 2015). Azonban az elmondható, hogy a vizsgált időszakban a hallgatói összlétszámnak kb. 1-2\%-a körül mozog a fogyatékos hallgatók aránya országosan. Statisztikai adatok szerint a 2018/2019-es tanévben a Pécsi Tudományegyetemnek 270 fogyatékos hallgatója volt. A PTE egyben az első magyarországi egyetem volt, amely a 2005/2006-os tanévben a speciális hallgatók megsegítésére létrehozta a Támogató Szolgálatot (Komjáthy 2012), mely azóta is tevékenyen jelen van az egyetem életében.

A következő - méltányos támogatást igénylő - csoport a szociálisan hátrányos helyzetủ és/vagy cigány/roma hallgatók köre (Cserti-Csapó-Orsós 2013), akiket felsőoktatásba kerülésük okán reziliensnek (academic resilience) tekintünk. A bekerüléshez szükség volt ugyanis sikeres közoktatási eredményekre, melyeket annak ellenére értek el, hogy sokféle akadály gátolta őket a hátrányos szocioökonómiai hátterük miatt (Agasisti et al. 2018). A 2. táblázatban számszerủen is látható, hogy a 2013 szeptemberében bevezetett

1 Debreceni Egyetem, Eötvös Lóránd Tudományegyetem, Szegedi Tudományegyetem. 
jogszabályváltozás (2013. évi XXVII. törvény 45. §) szigorodásának és a definíciók ${ }^{2}$ megváltozásának hatására jelentősen csökkent a hátrányos és halmozottan hátrányos helyzettel összefüggő többletpontszám jogosultságának lehetősége a korábbi évekhez képest (Proity 2019; Hegedüs 2016), és vélhetően ez is negatívan befolyásolta a szociálisan hátrányos helyzetűek felsőoktatásba való bejutási lehetőségét. A cigány/roma hallgatókról statisztikai adatok nem állnak rendelkezésünkre, ugyanis sem a Köznevelési Információs Rendszer, sem a Felsőoktatási Információs Rendszer nem nyújt etnikai hovatartozásra vonatkozó adatokat. A magyarországi támogató programok (Roma Szakkollégiumok) és különböző vizsgálatok alapján tudható, hogy a cigány/roma fiatalok alacsony arányban jutnak a felsőoktatásba, és onnan könnyen lemorzsolódnak (Trendl 2015). Ez a sajnálatos trend megfelel a nemzetközi szakirodalomban leírt hasonló jelenségeknek (Richardson 2018).

2. táblázat: A magyarországi felsőoktatásba $\mathrm{HH}$ vagy $\mathrm{HHH}$ jogcímen többletpontot benyújtott és abban részesült hallgatók száma és aránya a teljes hallgatói létszámhoz képest.

(Saját szerkesztés Proity 2019 alapán)

\begin{tabular}{|c|c|c|}
\hline Év & $\begin{array}{l}\text { Többletpontot benyújtók } \\
\text { létszáma (fó) }\end{array}$ & $\begin{array}{l}\text { Többletpontban részesültek } \\
\text { létszáma (fö) és aránya (\%) }\end{array}$ \\
\hline \multirow{2}{*}{2013} & \multirow{2}{*}{77710} & HH 5253 fó $(6,76 \%)$ \\
\hline & & HHH 12 fö $(0,02 \%)$ \\
\hline \multirow{2}{*}{2014} & \multirow{2}{*}{85983} & HH 3777 fö (4,39\%) \\
\hline & & HHH 103 fö $(0,12 \%)$ \\
\hline \multirow{2}{*}{2015} & \multirow{2}{*}{85931} & HН 9123 fó (1,06\%) \\
\hline & & HHH 88 fö $(0,1 \%)$ \\
\hline \multirow{2}{*}{2016} & \multirow{2}{*}{91569} & HH 747 fö $(0,82 \%)$ \\
\hline & & HHH 402 fö $(0,44 \%)$ \\
\hline \multirow{2}{*}{2017} & \multirow{2}{*}{88767} & HH 745 fö $(0,84 \%)$ \\
\hline & & HHH 323 fö $(0,36 \%)$ \\
\hline \multirow{2}{*}{2018} & \multirow{2}{*}{90624} & HH 651 fö (0,72\%) \\
\hline & & HHH 305 fö $(0,34 \%)$ \\
\hline
\end{tabular}

2013 őszéig az alacsony jövedelmű, szegény családokban felnövő gyerekeket sorolták a hátrányos helyzetủek közé. A besorolást objektív minősítés határozta meg: a család szociális helyzete alapján a jegyző által kiadott rendszeres gyermekvédelmi kedvezményre (RGYK) jogosító igazolás. Ezen belül halmozottan hátrányos helyzetűnek számított az a gyermek, akinek iskolázatlanok a szülei. 2013-tól az alacsony jövedelem mellé szükséges legalább egy hátránynövelő jellemzővel rendelkeznie az adott, hátrányos helyzetű kategóriába sorolt gyereknek. A jogszabály alapján hátránynövelő a szülők alacsony iskolai végzettsége, tartós munkanélkülisége, illetve az elégtelen lakáskörülmények. A halmozottan hátrányos helyzetü kategóriához a család szegénységét jelző RGYK mellett 2013-tól minimum további két kritériumnak kell teljesülnie a szülők alacsony iskolázottsága, tartós munkanélkülisége és az elégtelen lakáskörülmények közül (Varga 2015). 


\section{Az inkluzív támogatás dimenziói}

A PTE 10 karának dékánjai által nyújtott kérdőíves válaszok alapján megállapítható (3. táblázat), hogy leginkább az önálló kurzusok során $(N=7)$, önálló programokkal $(N=7)$, illetve más karokkal, egyetemekkel történő együttműködés keretein belül $(N=6)$ segítik a karok a fentiekben bemutatott csoportokat (Deli 2019). Ezeken kívül jóval kisebb arányban jelennek meg a környezet inkluzivitását növelő beavatkozások pl. a befogadásra érzékenyítő képzések $(N=5)$ az egyetem polgárai számára (3. táblá$z a t)$. A PTE az inkluzív szemlélet és az akadémiai kiválóság kialakításáért igyekszik az egyetemen kevésbé reprezentált hallgatói csoportokat támogatni különböző méltányos szolgáltatásokon keresztül, megteremtve ezzel az esélyegyenlőséget, azonban az inkluzív környezet kialakításában a PTE-n kevésbé hangsúlyos az oktatók vagy az egyéb munkatársak, személyzet felkészítése, ugyanis csak három kar említette ezt. Ez utóbbit hiányként azonosítjuk, mivel az inkluzív rendszer müködési feltételei között kulcsszerepet tölt be a megvalósítók felkészültsége, mint a befogadó intézményi klíma kialakításának egyik jelentős szempontja (Varga 2015: 7; Universities UK 2019).

3. táblázat: Támogatási formák a PTE-n a 2018/2019-es tanév őszi szemeszterében $(N=10)$

\begin{tabular}{lc}
\hline A támogatás dimenziói a PTE-n & Kar $(\mathrm{N}=10)$ \\
\hline Önálló kurzus & 7 \\
Önáló program & 7 \\
Más karon/egyetemen zajló támogató programmal van együttmüködés & 6 \\
Kari költségvetésben tervezetten megjelenik a támogató programok finanszírozása & 5 \\
Befogadásra érzékenyítő képzés hallgatóknak & 5 \\
Mentálhigiénés szolgáltatás nyújtása, életvezetési tanácsadás & 4 \\
Kurzusok része & 3 \\
Önálló szak & 3 \\
Egyéb anyagi jellegú támogatás hallgatóknak & 3 \\
Egyéb nem anyagi jellegú támogatás hallgatóknak & 3 \\
Önálló szervezeti egység & 2 \\
Csak pénzbeli juttatás hallgatóknak & 2 \\
Befogadásra érzékenyítő képzés oktatóknak & 2 \\
Befogadásra érzékenyítő képzés adminisztratív dolgozóknak & 2 \\
Befogadás fókuszában lévő célcsoport számára önálló közösségi tér & 2 \\
A támogató programok megjelennek a kari SZMSZ-ben & 1 \\
Van külső/nem felsőoktatási támogató programot múködtető szervezettel kapcsolat & 1 \\
Befogadást működtető munkatársak számára önálló helyiség & 1 \\
\hline
\end{tabular}

A befogadást célzó programok vezetőivel készített félig strukturált mélyinterjúk $(N=10)$ során megkíséreltük felmérni, hogy milyen hallgatói csoportokkal, milyen módszerekkel és tapasztalatokkal, illetve milyen jövőbeli tervekkel végzik munkájukat az inklúzióval foglalkozó programok. Az interjúk tartalomelemzése során kulcsszavak 
és -kifejezések előfordulásának gyakoriságát vizsgáltuk, azok szövegkörnyezetét is figyelve. Ezek alapján elemeztük a befogadást támogató programok jellemzőit a létrejöttük, a célkitűzéseik, a működésük sikerei és akadályai, valamint a jövőbeli tervek alapján.

A programok létrejöttét, megalakulásának körülményeit vizsgálva elmondható, hogy az adott, inklúzióra igényt tartó hallgatócsoportok észlelését követően kivétel nélkül individuális megvalósulások szerint, az adott kar vagy szervezeti egység kezdeményezésére (tehát nem összegyetemi szinten) indultak el a programok. Az indulás körülményeire fókuszáló kérdéseknél elhangzott válaszokban a "pénz" (8) szó előfordulása és annak szövegkörnyezete („nem kell több”, „sikerült rá pénzt keríteni”, „megszünt a Kar kezdeti elvárása, hogy pénzt hozzon be a müködésünk”, „kevés pénzből indultunk”, „a diákok nem a pénzért csinálják") jól mutatja, hogy az alulról jövő kezdeményezéseknek nem szabott gátat az anyagi keretek szűkössége. A „kezdeményezés” szó megjelenése (5) és annak szövegkörnyezete rámutat arra, hogy a programvezetők maguk is úgy látják, hogy alulról jövő szerveződések mentén jöttek létre programjaik („társadalmi kezdeményezés volt”, „ez hallgatói kezdeményezés”, „alulról jövő kezdeményezés”, „a Fullbright ösztöndíjasok kezdeményezők voltak"), illetve hogy a további lépéseket is ilyen irányból lenne lehetséges folytatni („az alulról jövő kezdeményezéseket kell összefogni és támogatni”).

Elmondható, hogy amint azt más inklúziós intézményfejlesztési programoknál is tapasztalhatjuk, a kiemelt figyelmet érdemlő hallgatói csoportok számára jöttek létre a programok, felismerve ezen csoportokba tartozók egyéni szükségleteit. A „közösség” szó megjelenése (9) jelzi, hogy az inklúzió fókuszban lévő célcsoport kohéziója meghatározó jellemzője a programok kezdeti és jelenlegi működésének is („elismerésre méltó és jó ebbe a közösségbe tartozni”, „a szakkollégium pillére a közösség”, „ez egy kari közösség”, „közösségfejlesztő workshopot szervezünk”, ,a közösségben kialakuló emberi kapcsolatok fontosak”, „közösségi programok megvalósítása a fö programelemünk”, „dolgozni kell azon, hogy a közösség megmaradjon”, „a közösségi tér fontos”), kevés említés esik a közösség nyitásáról a többi egyetemi polgár felé. A célcsoportok jellegét vizsgálva megfigyelhető, hogy az elmúlt időszakban és jelenleg is elsősorban külföldi hallgatók inklúziójára törekednek a PTE múködő kari programjai - ahogyan ezt a tényt már a kérdőives adatfelvétel is feltárta. A „külföldi [hallgatók]” kifejezés kiemelkedő előfordulása (39) jól mutatja, hogy milyen egyértelmü és erős igény mutatkozik a más kultúrákból érkezők egyetemi beilleszkedésére mind egyéni („krízisvonalat működtetünk külföldi hallgatók számára”, „külföldi hallgatók részéről jelentkezett az igény”), mind egyetemi („nyitni kell feléjük, ez kari elvárás”) szinten. Figyelemre méltó a "szakkollégium” megjelenése (28) - számos programnál az egyéb téren hiányos erőforrásokat a szakkollégiumi hallgatók pótolják önkéntes munkájukkal. Legalább ilyen fontos a „mentorok” (28) gyakran önkéntes munkája. A karokon tanító oktatók segítsége mellett („segítség” - 14) a programokkal érzékelhetően igyekeznek megragadni minden lehetőséget, mely támogathatja kezdeményezéseiket („a coach kollégától kapott a hallgató segítséget”, „önéletrajzírásban nyújtott segítséget nekünk”, „[a Külügyi Kapcsolatoktól] kaptunk rá pénzügyi segítséget”, „egyetemi polgárok egyetemi polgároknak nyújtanak segítséget”, „hallgatók kérték az oktatók segítségét”, „dékáni segítséget kapunk mindenben”, „a közösségi térben lehet segítséget kapni”, „[középiskolai] tanárok segítségét kértük”, „a StudyHub tanulmányi segítséget nyújt”). Az alulról jövő kezdeményezésekre globálisan jellemző improvizatív, flexibilis erőforrásmozgósítás tehát megfigyelhető ebben az esetben is. 
A programok működése során tapasztalt kihívások („nehéz” - 16, „akadály” - 6, „korlát” - 3) jól mutatják, milyen nehézségekkel és feladatokkal kell megküzdeni minden inkluzív programnak, mely még nem érte el az intézményes müködés szintjét. A karokon belül jól működő gyakorlatok létjogosultságát megkérdőjelező attitűd („nehéz a hatékonyságot ismertetni a Kar felé”, „nehéz az, hogy a Karok elfogadják a létezésünket vagy létjogosultságunkat”), az intézményi szinten korlátozott erőforrások („kapacitás és időprobléma nehézsége”, „a szervezeti átalakulás által okozott nehézségek”), illetve a hosszabb távú kilátások bizonytalansága is közös probléma a programok megvalósítása során („nehéz áttörni a falakat”, „nehéz hosszú távú célokat meghatározni”).

A programvezetők motivációját alapvetően az egyéni sikerek jelentik („büszke” 6, „siker” - 17). A programok folyamatos müködésének záloga az abban résztvevőket érő pozitív visszacsatolás („büszke vagyok rá, hogy megöleltek”, „számomra van értelme”, „értéket teremtünk”, „büszke vagyok rá, hogy legalább valami ilyennel foglalkozik”, „konkrét esetekre vagyok büszke”, „a megvalósult előadásunkra vagyok büszke”, „a hallgatók büszkék rá, hogy a szakkollégiumhoz tartoznak”, „ez nekem egy személyes siker"). Az intézményi szinten történő koordináció hiányában a jövőre vonatkozó tervek elsősorban nem az inklúzió horizontális kiterjedésére vonatkoznak, sokkal inkább a programok fennmaradását célozzák („cél” - 15, „terv” - 8). Az inkluzív szemlélet és a hétköznapi működés mikroszinten történő kiterjesztése és fejlesztése mind erőforrások, mind intézményi stratégia hiányában elsődleges fontosságú a programvezetők számára, ahogy a jelenlét és a szolgáltatás népszerűsítése is („célunk, hogy stabilizálódjunk a PTE életében”, „bővítenénk a tanácsadó csapatunkat”, „aktualizálnánk a módszereinket”, „egyértelművé szeretnénk tenni működésünket”, „célunk a közösségi tér ismertebbé válása”, rendszerszintü változásokat szeretnénk elérni”, „a hallgatóknak napi szintü segítséget szeretnénk nyújtani”, „célunk a népszerüsítés”).

$\mathrm{A} z$ inklúzió rendszerszintü kiterjedésének igényét és végső célját jól mutatja az egyik programvezető által megfogalmazott cél: „Azt szeretnénk, hogy végül majd ne legyen szükség a Támogató Szolgálatra."

\section{Összegzés}

Kutatásunk alapján megállapítható, hogy a PTE az elmúlt években határozottan elindult a befogadóvá válás felé, és a különböző karokon futó, inklúziót célzó programok követik a nemzetközi színtéren is megfigyelhető progressziót. A programok a legtöbb esetben a külföldi hallgatókat célozzák, de léteznek hátrányos helyzetű, cigány/roma, illetve fogyatékos hallgatókat támogató programok is. A programok legtöbbje célcsoportjuk azonosítását követően alulról építkező kezdeményezésként és egymástól függetlenül indult el. További jellemzőjük, hogy aktuális igényekre szabott, döntően támogató tevékenységek, melyek az intézményi szinten kevés vagy hiányzó erőforrások híján egyéni finanszírozási megoldásokkal és a rendelkezésre álló humán erőforrásokkal igyekeztek elérni rövid távú céljaikat - azaz a célcsoportok egyetemi környezetbe történő befogadását. A korábbi célcsoportok mellett megjelenő újabb csoportok és változó igények nem feltétlenül találtak támogató programokra, hiszen a szabad erőforrásokat, a tenni vágyó egyetemi polgárokat a már meglévő és müködő programok nagyrészt lefoglalták. Jellemző az is, hogy a vizsgált programok elsősorban a támogatott célcsoportból alkotott közösségben dolgoznak, és nagyon kevés (ha van) azon tevékenységük száma, melyek 
a célcsoport aktivitására építve az egyetemi polgárokat mozgósítva (pl. érzékenyítve) hatnak az intézményi környezetre is.

A vizsgált programok jelenlegi múködését tekintve elszigeteltnek mondhatók, mivel gyakorlatilag nem, vagy csak esetlegesen tudnak egymás létezéséről. Az együttműködés kialakulása az információáramlás és a közös kommunikációs színtér hiánya miatt eleve lehetetlen volt. Napjainkban indult a törekvés a PTE inkluzív egyetemmé válására - felsővezetői elköteleződéssel. A „Befogadó Egyetem”3 elnevezésű kezdeményezés - mint „ernyőszervezet” - igyekszik megteremteni azt a fórumot, melyen keresztül a programok szervezői és lebonyolítói megismerhetik egymás munkáját, létrejöhet egy olyan diskurzus, mely előremozdítja az intézményi szintű befogadóvá válás folyamatát.

A vizsgálati eredmények összességére tekintve megállapítható, hogy a befogadóvá válás harmadik lépcsőfokának (1. ábra) ismérvei érzékelhetők a PTE-n. Az intézmény felsővezetése részéről elköteleződés tapasztalható, ismertek a befogadás fókuszában lévő hallgatói csoportok, sokféle támogató program müködik, a Karok nyitottak az együttműködés felé, és több esetben szóba került a környezet érzékenyítésének kiterjesztése minden egyetemi polgár számára. Ez utóbbi elengedhetetlen előfeltétele a rendszerszintü befogadásnak.

Amennyiben a vizsgált folyamatok jövőjét, kívánatos fejlődését nézzük, több ponton szükséges beavatkozás. A meglévő kezdeményezések megerősítése, kiterjesztése az együttmüködések által lehetséges. Fontos, hogy a külföldi hallgatók mellett a személyes vagy társadalmi hátránnyal küzdők is több figyelmet kapjanak, számarányuk növekedjen. Mindehhez a koordinációt végző szervezeti egység megerősítésére és a folyamatok tudományos követésére is szükség van. Az inkluzívvá válás utolsó lépcsőfoka az a stabil vezetői elköteleződéssel jellemezhető és tudatos fejlesztési folyamat, melyben a támogató programok a támogatott hallgatói csoportok öntevékenységére építve a diverzitás értékét közvetítik az egyetem valamennyi polgára felé. Ezt az „érzékenyítést” egészítik ki azok a célzott beavatkozások, melyek az egyetemi környezet - terek, curriculum, polgárok változását hozzák. Vizsgálatunk szerint a Pécsi Tudományegyetem törekszik megteremteni a méltányosságot (equity) minden hallgatói csoport számára, és tudatosan készül arra, hogy a növekvő diverzitást a környezet inkluzivitásának fejlesztésével az egyetemi kiválóság szolgálatába állítsa.

\section{IRODALOM}

Agasisti, T., Avvisati, F., Borgonovi, F. \& Longobardi, S. (2018) Academic Resilience: What Schools and Countries Do to Help Disadvantaged Students Succeed in PISA. Paris, OECD.

Arató, F. \& Varga, A. (2015, eds) Inclusive University: How to Increase Academic Excellence Focusing on the Aspects of Inclusion. (Autonomy and Responsibility Study Volumes IV.) Pécs, University of Pécs, Faculty of Humanities, Institute of Education. http://kompetenspedagogus.hu/sites/default/files/arato-f-varga-a-inclusive-university-univ-pecs-2015. pdf [Letöltve: 2019. 09. 25.]

A Befogadó Egyetem elnevezésű fejlesztésről bővebben olvasható ezen a linken: http://befogadoegyetem. pte.hu/en/content/what_inclusive_university 
Arató F. \& Varga A. (2018) Befogadó Egyetem. In: Pusztai G. \& Szigeti F. (eds) Lemorzsolódás és perzisztencia a felsőoktatásban. Debrecen, Debreceni Egyetemi Kiadó. pp. 189-206.

Baumann, G., Bustillos, L., Bensimon, E., Brown, Ch. \& Bartee, R. (2005) Achieving Equitable Educational Outcomes with All Students: The Institution's Roles and Responsibilities. Washington (D.C.), Association of American Colleges and Universities (USA).

Casey, L. (2016) The Casey Review: A Review into Opportunity and Integration. London, Department for Communities and Local Government. https://assets.publishing.service. gov.uk/government/uploads/system/uploads/attachment_data/file/575973/The_Casey_ Review_Report.pdf [Letöltve: 2019. 09. 20.]

Chang, M. J. (2001) Is it More than about Getting Along? The Broader Educational Implications of Reducing Students' Racial Biases. Journal of College Student Development, Vol. 42. No. 2. pp. 93-105.

Chang, M. J., Astin, A. W., \& кім, D. (2004) Cross-Racial Interaction among Undergraduates: Some Consequences, Causes, and Patterns. Research in Higher Education, Vol. 45. No. 5. pp. 529-553.

Claeys-Kulik, A.-L. \& Jorgensen, T. E. (2018) Universities' Strategies and Approaches towards Diversity, Equity and Inclusion. Examples from across Europe. Brussels, European University Association.

Connor, H., Tyers, C., Modood, T. \& Hillage, J. (2004) Why the Difference? A Closer Look at Higher Education Minority Ethnic Students and Graduates. Research Report No. 552. London, Department for Education and Skills.

Cserti Csapó T. \& Orsós A. (2013) A mélyszegénységben élők és a cigányok/romák helyzete, esélyegyenlősége. Extreme Poverty and Roma Peoples' Situation and Opportunities. In: VArga A. (ed.) Esélyegyenlöség a mai Magyarországon. Pécs, PTE BTK NTI Romológia és Nevelésszociológia Tanszék. pp. 99-120.

Deli K. (2019) A támogatási sokszínűség dimenziói a Pécsi Tudományegyetemen. In: Karlovitz J. T. \& Torgyik J. (eds) Szakmódszertani és más emberközpontú tanulmányok. Komárno, International Research Institute. pp. 217-226.

Duncan, J. M. (2014) Understanding Disability Rights in a Global Context. In: S. N. Asumah \& M. Nagel (eds) Diversity, Social Justice, and Inclusive Excellence - Transdisciplinary and Global Perspectives. Albany (NY), State University of New York Press. pp. 363-378.

Hegedűs R. (2016) Számok- arányok- mintázatok a felsőoktatásba felvett hátrányos helyzetüek esetében. Modern Geográfia, Vol. 10. No. 3. pp. 1-14.

Hurtado, S., Alvarez, C. L., Guillermo, W. Ch., Cuellar, M. \& Arellano, L. (2012) A Model for Diverse Learning Environments the Scholarship on Creating and Assessing Conditions for Student Success. In: J. C. Smart. \& M. B. Paulsen (eds) Higher Education: Handbook of Theory and Research, Higher Education: Handbook of Theory and Research 27. Springer Science and Business Media B.V. New York (NY), Springer. pp. 41-122.

Hurtado, S. \& Ruiz, A. A. (2015) Thinking about Race: The Salience of Racial Identity at Two- and Four-Year Colleges and the Climate for Diversity. Journal of Higher Education, Vol. 86. No. 1. pp. 127-155.

Комја́тну Zs. (2012) Fogyatékos hallgatók a pedagógusképzésben. Képzés és Gyakorlat. Neveléstudományi Folyóirat, Vol. 10. Nos 1-2. pp. 86-102.

LAKI I. (2015) A felsőoktatás hallgatói - a fogyatékossággal élő hallgatók felsőfokú tanulmányai. In: Karlovitz J. T. (ed.) Fejlödö jogrendszer és gazdasági környezet a változó társadalomban. pp. 340-348. 
Milem, J., Chang, M. \& Antonio, A. (2005) Making Diversity Work: A Researched Based Perspective. Washington (D.C.), Association of American Colleges and Universities.

Prorty P. (2019) Inklúzió a felsőoktatásban. A hátrányos helyzet igazolására benyújtandó dokumentumok elemzése és a hátrányos helyzetü jelentkezök létszámadatainak változása 2008-2018 között. Pécs, PTE BTK Neveléstudományi Intézet.

Rétry E. (2013) Befogadás, méltányosság, az inkluzív pedagógia rendszere. Pécs, Comenius Oktató és Kiadó Kft. http://epa.oszk.hu/00000/00035/00161/pdf/EPA00035_ upsz_2013_11-12_098-101.pdf_[Letöltve: 2019.08.29.]

Richardson, J. T. E. (2015) The Under-Attainment of Ethnic Minority Students in UK Higher Education: What We Know and What We Don't Know. Journal of Further and Higher Education, Vol. 39. No. 2. pp. 278-291. https://www.tandfonline.com/doi/ full/10.1080/0309877X.2013.858680?scroll=top\&needAccess=true [Letöltve: 2019. 08. 30.]

SzÉLl K. (2016) Külföldi támogatási gyakorlatok. In: A felsőoktatás szociális dimenziója. Hátrányos helyzetű csoportok hozzáférése és részvétele a felsőoktatásban című kutatás. Tempus Közalapítvány.

Trendl, F. (2015) The Implementation of an 'Inclusive Environment' in a University College. In: Arató F. \& Varga A. (eds) Inclusive University: How to Increase Academic Excellence Focusing on the Aspects of Inclusion (Autonomy and Responsibility Study Volumes IV.) Pécs, University of Pécs, Faculty of Humanities, Institute of Education. pp. 127-136. http://kompetenspedagogus.hu/sites/default/files/arato-f-varga-a-inclusiveuniversity-univ-pecs-2015.pdf [Letöltve:2019. 08. 30.]

Universities UK (2019) Black, Asian and Minority Ethnic Student Attainment at UK Universities: Case Studies. London, Universities UK. https://www.universitiesuk.ac.uk/ policy-and-analysis/reports/Documents/2019/bame-student-attainment-uk-universitiescase-studies.pdf [Letöltve: 2019.08 .25 .]

UNESCO (1994) Salamanca Statement and Framework for Action on Special Needs Education. Salamanca, Spain, 7-10 June 1994.

UNESCO (2005) Guidelines for Inclusion: Ensuring Access to Education for All. UNESCO, Paris.

UNESCO (2009a) Policy Guidelines on Inclusion in Education. United Nations Educational, Scientific and Cultural Organization. Paris.

UNESCO (2009b) Defining an Inclusive Education Agenda: Reflections around the 48th Session of International Conference on Education. Geneva, UNESCO IBE.

VArga A. (2015) The Theory and Practice of Inclusion. Pécs, University of Pécs, Faculty of Humanities, Institute of Education. https://wlislocki.pte.hu/sites/wlislocki.pte.hu/files/ files/eng_inkluzio_beliv_full.pdf [Letöltve: 2019. 08. 15.]

VArga A. (2015) Hátrányos helyzet és iskolarendszer. In: Kozma T., Kiss V. Á., JancsáK Cs. \& Kéri K. (eds) Tanárképzés és oktatáskutatás. Debrecen, HERA. pp. 621-633.

Williams, D. A., Joseph, B. B. \& Shederick, A. Mc. (2005) Toward a Model of Inclusive Excellence and Change in Postsecondary Institutions. Washington (D.C.) Association of American Colleges and Universities.

A cikk a Creative Commons Attribution 4.0 International License (https://creativecommons.org/licenses/ by/4.0/) feltételei szerint publikált Open Access közlemény, melynek szellemében a cikk bármilyen médiumban szabadon felhasználható, megosztható és újraközölhető, feltéve, hogy az eredeti szerző és a közlés helye, illetve a CC License linkje és az esetlegesen végrehajtott módosítások feltüntetésre kerülnek. (SID_1) 